Reprod. Nutr. Dévelop., 1984, 24 (5A), 623-631.

\title{
Superovulation and egg transfer in the ewe
}

\author{
SUzanne TORRĖS, Y. COGNIÉ (*) \\ Station de Physiologie animale, I.N.R.A., \\ 78350 Jouy-en-Josas, France. \\ (*) Laboratoire de Recherche sur la Fertilité femelle, I.N.R.A., \\ Nouzilly 37380 Monnaie, France.
}

Summary. 102 Prealpes du Sud donor ewes were superovulated by a treatment with vaginal sponges impregnated with $40 \mathrm{mg}$ of FGA. When the sponges were withdrawn at 14 days, follicular maturation was stimulated in these ewes with $12 \mathrm{mg}$ of porcine pituitary extract (pFSH). The recipient ewes were treated i.m. with 500 IU of PMSG.

Different batches of pFSH (batch pFSH1/Group A; batch pFSH2 : groups B and C) were used; a total of $12 \mathrm{mg}$ was given in 4 injections of $3 \mathrm{mg}$ each (groups $A$ and $B$ ) or in decreasing doses of $5,3,2$, and $1 \mathrm{mg}$ (group $\mathrm{C}$ ).

The embryos were recovered at D6 and transferred after 1 or $5 \mathrm{~h}$ of storage in medium 199 or medium B2 (Ménézo, 1976) $+10 \%$ FCS at either 37 or $20^{\circ} \mathrm{C}$ (B only). Surgery was used to recover the embryos and place them (one per uterine horn) in the recipients.

pFSH1 induced estrus $24 \mathrm{~h}$ after sponge withdrawal in $100 \%$ of group A ewes. When the LH level was lower (pFSH2; groups B and C), only $62.5 \%$ of the ewes came on heat at $24 \mathrm{~h}$.

pFSH2 induced 8.1 corpora lutea per ewe (groups $\mathrm{B}$ and $\mathrm{C}$ ) vs 4.6 in group $\mathrm{A}$ (pFSH1) and twofold more viable embryos were recovered in groups $B$ and $C$ than in group $A(6.1$ vs 2.7). In relation to the number of corpora lutea, 59, 69 and $80 \%$ of viable embryos were recovered in groups $A, B$, and $C$, respectively.

There was a positive correlation between the number of corpora lutea and the number of morulae recovered. The regression line of each group has been plotted.

One or 5-h storage in medium B2 at $37{ }^{\circ} \mathrm{C}$ gave 25 and $17 \%$ of ewes lambing with an embryonic survival rate of 17.6 and $10.5 \%$. Storage in medium 199 gave better results only for 1 -h storage (60 and $47 \%$ ) ; results after $5 \mathrm{~h}$ were comparable to those obtained with B2 (25 and $17 \%$ ). When the temperature was lowered to $20^{\circ} \mathrm{C}$ (medium B2) after 1 and $5 \mathrm{~h}$ of storage, $66 \%$ of these ewes lambed and embryonic survival rose to $47 \%$ instead of $14 \%$.

The origin of the pituitary extract determined whether or not good superovulation was obtained. However, the response varied greatly from one ewe to another. Embryonic storage at $37^{\circ} \mathrm{C}$ was limited ; $20^{\circ} \mathrm{C}$ markedly improved embryonic survival after transfer.

\section{Introduction.}

Much work has been done on the production of eggs and their transfer in the ewe. Experimentation has usually been limited to the laboratory and there has been little practical application. These experiments have determined the conditions requisite to successful transfer. 
When the age of the eggs recovered from the donor ewe is identical to or not more than $12 \mathrm{~h}$ different from the age of the corpora lutea of the recipient ewe, the eggs develop normally after transfer (Moore and Shelton, 1964 ; Rowson and Moor, 1966).

It is therefore necessary to control precisely the onset of oestrus and ovulation ; this is obtained by associating progestagen, given by vaginal route (Robinson, 1965), and an injection of PMSG when the progestagen is withdrawn (Cognié et al., 1970).

For superovulation, horse (Shelton and Moore, 1967) and porcine (Armstrong and Evans, 1983) pituitary extracts seem better than PMSG for reducing (at an equal number of ovulations) the excess of large, non-ovulatory follicles and for improving the quality of the transferred embryos.

In the present work, we present results on the superovulation of donor ewes by a treatment associating a progestagen and porcine pituitary extracts $(\mathrm{pFSH})$ and we show the effect of embryonic storage conditions before transfer on the fertility rate of recipient ewes.

\section{Material and methods.}

A total of 102 Prealpes du Sud ewes were treated during the normal reproductive season (October-December 1982).

Sponges impregnated with $40 \mathrm{mg}$ of FGA (1) were put in the vagina of the ewes between D1 and D9 of the cycle and were withdrawn after 14 days. When the sponges were withdrawn, the recipient ewes were given an intramuscular injection of 500 i.m. PMSG (1).

Follicular maturation was stimulated in the donor ewes with a total of $12 \mathrm{mg}$ of pFSH given in four injections i.m. in the morning and the evening for two days. Two different lots of commercial pFSH (Burns, Biotec, Omaha, USA) were used: (1) lot $A=546 \mathrm{~B} 81=\mathrm{pFSH} 1 \quad(14$ ewes $)$ and (2) lot $\mathrm{B}+$ lot $\mathrm{C}=562 \mathrm{C} 82=\mathrm{pFSH} 2$ (lot $\mathrm{B}: 11$ ewes; lot $\mathrm{C}: 21$ ewes). Variations in the LH activities of commercial pituitary extracts measured by $\mathrm{Y}$. Combarnous ${ }^{(2)}$ justified separating the results obtained on superovulation according to the different origins of the pFSH.

Constant ( $4 \times 3 \mathrm{mg}$ : lots $\mathrm{A}$ and $\mathrm{B}$ ) or decreasing (5-4-2-1 $\mathrm{mg}$ : lot $\mathrm{C}$ ) doses of $\mathrm{pFSH}$ were injected; in all cases, the last injection was given $12 \mathrm{~h}$ after the sponges were withdrawn.

Immediately after sponge withdrawal, the onset of oestrus was detected twice a day using vasectomized rams, and $24 \mathrm{~h}$ after detection 200 million spermatozoa were placed in each uterine horn of the donor ewes by surgical route.

Do being the day of onset of oestrus, the embryos were recovered six days later (D6) in the donor ewes. After general anesthesia and opening the abdominal

(1) FGA (fluorogestone acetate) and PMSG (pregnant mare serum gonadotrophin) were supplied by Intervet $(49000$ Arigers).

$\left.{ }^{2}\right)$ Laboratoire de Physiologie de la Reproduction, INRA, Nouzilly, 37380 Monnaie. 


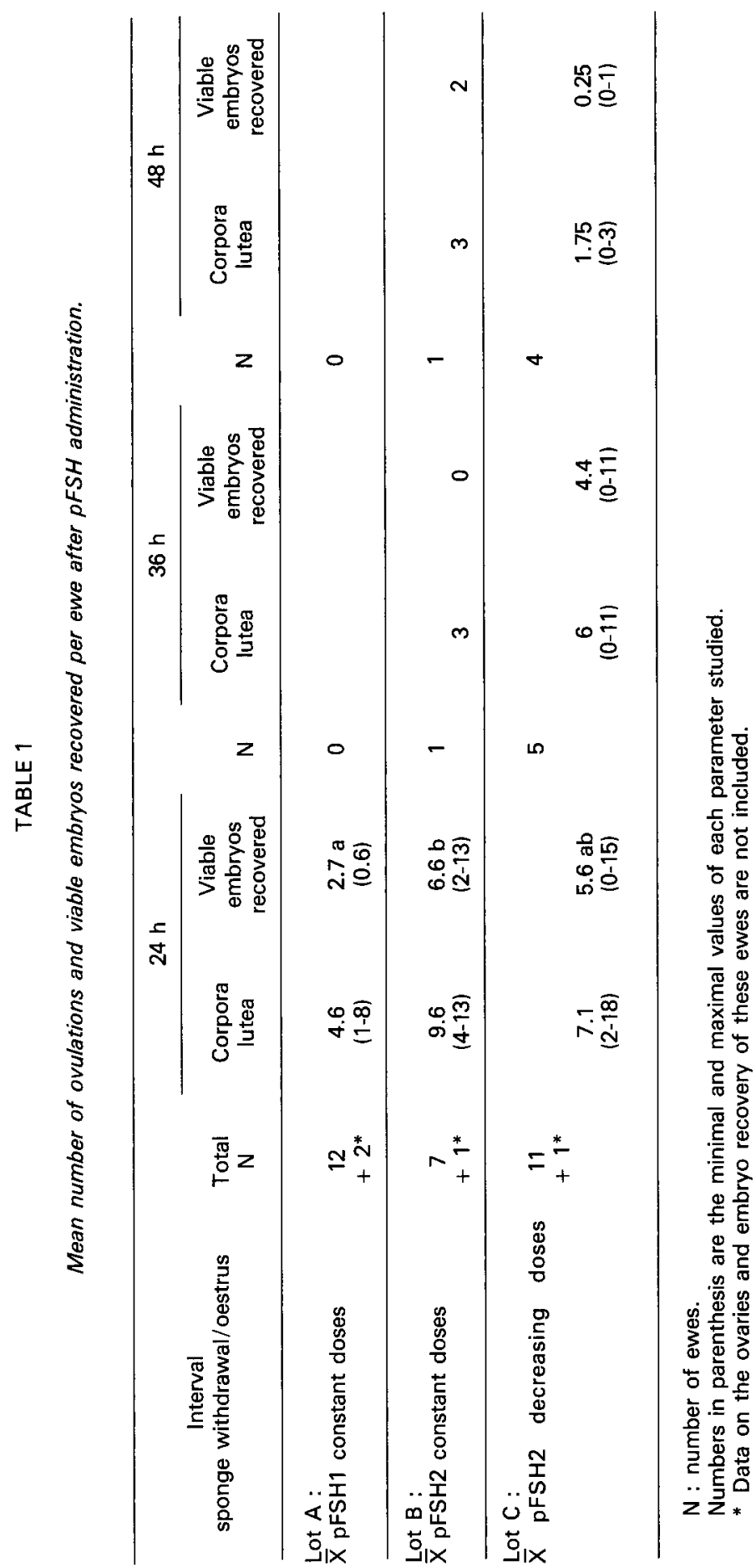


cavity, $15 \mathrm{ml}$ of medium 199 with $10 \%$ foetal calf serum (FCS) were injected at the base of each uterine horn and collected through the infundibulum (Hunter, et al., 1955). We selected viable embryos and stored them for 1 or $5 \mathrm{~h}$ at either $37^{\circ} \mathrm{C}$ (24 embryos) or $20^{\circ} \mathrm{C}$ (18 embryos) in medium B2 (Ménézo, 1976) + $10 \%$ FCS under an atmosphere of air $+5 \% \mathrm{CO}_{2}$. Fourteen embryos were also stored for 1 or $5 \mathrm{~h}$ at $37^{\circ} \mathrm{C}$ before transfer in the same medium as that used for washing the uterine horns of the donor ewes (199+10\% FCS).

Using a catheter, two embryos were then placed surgically in each recipient.

The rate of gestation was estimated at 18 days after the end of the hormone treatment by progesterone assay in peripheral blood and by the proportion of transferred ewes lambing.

The $\chi^{2}$ test for comparison of percentages of pregnant females was used. Linear regression with a zero intercept and the coefficient of correlation between the number of viable embryos and of corpora lutea were calculated.

\section{Results.}

In the donor ewes superovulated with pFSH1, oestrus was detected in $100 \%$ of lot A ewes and in $62.5 \%(p=0.05)$ of lot B $+C$ ewes (treated with pFSH2) $24 \mathrm{~h}$ after the sponges were withdrawn. Respectively 21.9 and $15.6 \%$ of these ewes came on heat 36 and $48 \mathrm{~h}$ after the vaginal sponges were withdrawn (table 1). The injection of constant (lot $\mathrm{B}$ ) or decreasing (lot $\mathrm{C}$ ) doses of $\mathrm{pFSH} 2$ had no significant effect on the onset of oestrus.

In recipient ewes, oestrous behaviour appeared $36 \pm 4 \mathrm{~h}$ after the end of the FGA-PMSG treatment.

Two, 2 and 1 ewes of lots A, B and C, respectively, were not included in the results of the superovulation treatments shown on table 1 due to either early corpus luteum regression or to embryonic loss because of rupture of the uterine horns.

The administration of pFSH2 pituitary extract induced a better ovarian response (8.1) corpora lutea per ewe in lots $\mathrm{B}+\mathrm{C}$ vs 4.6 in lot $\mathrm{A}$ with pFSH1 and 2-fold more viable embryos were recovered in lots $B$ and $C$ than in lot $A$ in ewes which were on heat $24 \mathrm{~h}$ after withdrawal of the vaginal sponge. Ewes which came on heat later had a lower average ovarian response and a lower percentage of good embryos.

In ewes in which oestrus began at about $24 \mathrm{~h}, 80 \%$ of the embryos were recovered in lots $\mathrm{B}+\mathrm{C}$ and $68 \%$ in lot $\mathrm{A}$ (non-significant difference). With regard to the number of corpora lutea, 59, 69 and $80 \%$ in lots $A, B$ and $C$, respectively, were normal morulae or blastocysts, the difference being significant only between lots $A$ and $C(P<0.05)$.

On the contrary, the percentages of recovery and viability in 9 ewes in lot $C$, coming on heat after $24 \mathrm{~h}$, were identical to those of lot A ewes (table 2).

Superovulation with FSH gives about $69 \%$ of transplantable morula ; with PMSG we obtain only $26 \%$ (Wintenberger-Torrès, 1967).

Out of the total 185 eggs recovered, development was retarded in 7 considered as non-viable and in 12 which were not fertilized. Absence of 


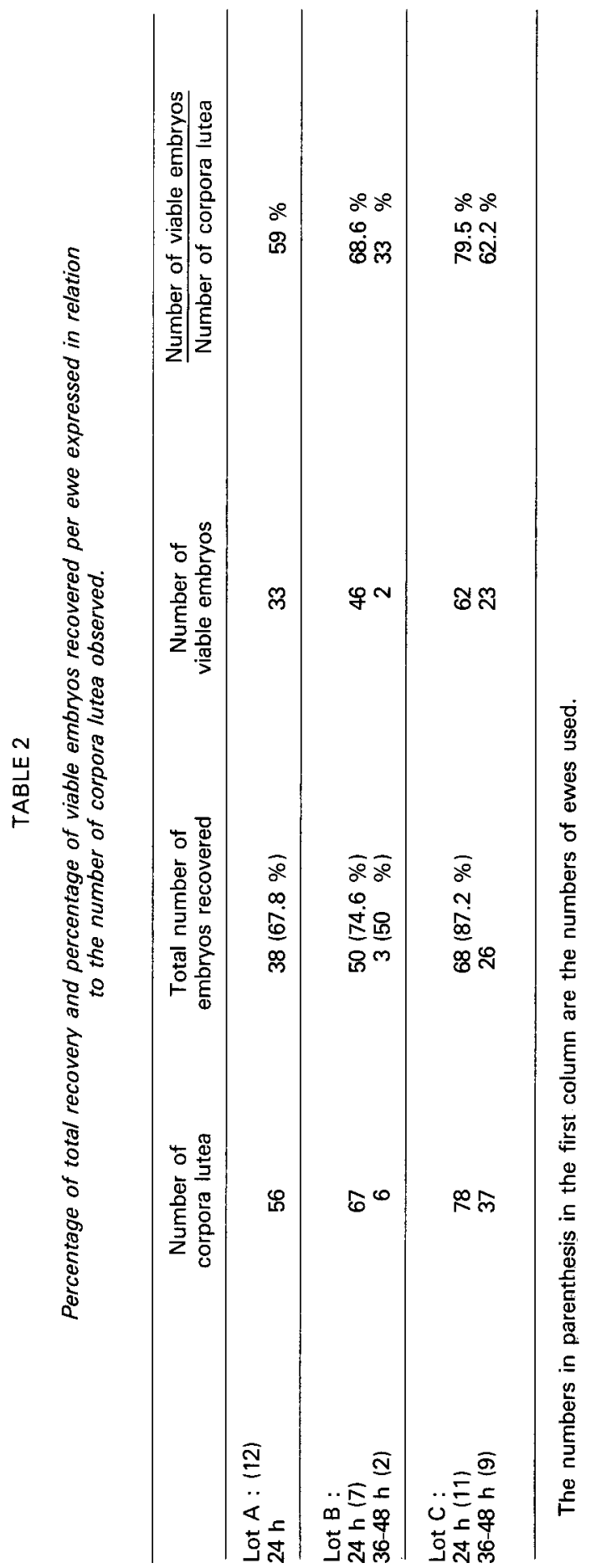


fertilization did not seem to be related to ovulation rate or to the superovulation treatment. We observed 2, 4 and 6 unfertilized eggs in lots A, B and C, respectively, and the distribution had no relation with the number of corpora lutea.

There was a positive correlation between the number of corpora lutea and the number of morulae recovered. The lowest coefficient corresponding to lot $A$ was due to 4 ewes which had 1 to 3 corpora lutea but gave no embryos. A regression line was plotted for each lot (fig. 1).

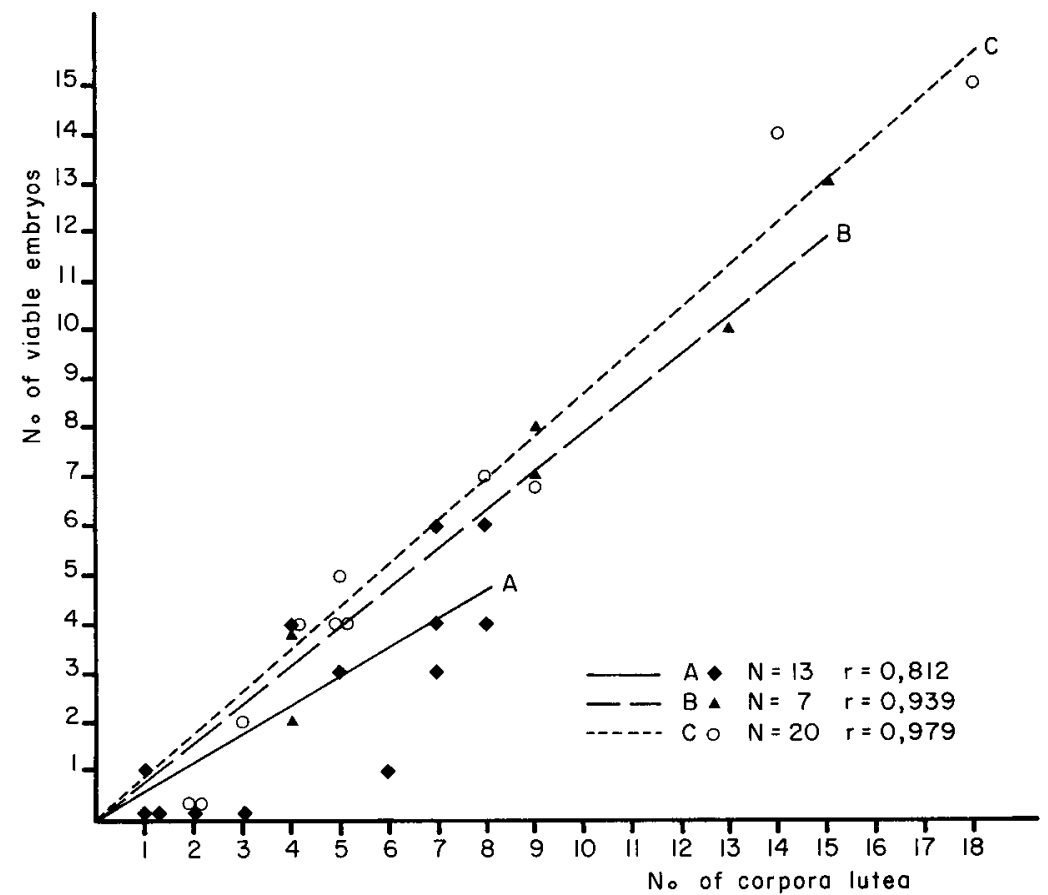

FIG. 1. - Correlation between the number of corpora lutea and the number of morulae recovered.

Since 5 to 6 eggs per ewe were recovered and two per recipient were surgically transferred, it was necessary to store the morulae for some time.

One hour and $5 \mathrm{~h}$ storage in medium B2 at $37{ }^{\circ} \mathrm{C}$ gave 25 and $17 \%$, respectively, of ewes lambing (table 3 ) and a corresponding blastocyst survival of 17.6 and $10.5 \%$. When B2 was replaced by 199 , the results were better only for $1 \mathrm{~h}$ storage $(60 \%$ and $47 \%)$; for $5 \mathrm{~h}$ storage the rates of gestation $(25 \%)$ and embryonic survival $(17 \%)$ were comparable to those obtained with B2.

Lowering the storage temperature of embryos in medium B2 significantly improved embryonic survival rate $\left(47\right.$ vs 14 for $20^{\circ} \mathrm{C}$ and $37^{\circ} \mathrm{C}$, respectively ; $\mathrm{P}<0.05)$. After 1 and $5 \mathrm{~h}$ of storage at $20^{\circ} \mathrm{C}, 66 \%$ of the ewes lambed.

When the embryos were stored at $37^{\circ} \mathrm{C}, 50 \%$ (8/16 ewes) of the ewes diagnosed as pregnant by plasma progesterone assay at 18 days did not lamb and 
returned to heat between 22 and 70 days, indicating a more or less early rate of embryonic loss. This loss was 2-fold less (2/16 ewes) when the storage temperature was lowered to $20^{\circ} \mathrm{C}$. Given the low number of recipient ewes concerned, this difference was non-significant.

TABLE 3

Results of transfers.

\begin{tabular}{|c|c|c|c|c|c|}
\hline $\begin{array}{l}\text { Medium-Time } \\
\text { Storage temperature }\end{array}$ & $\begin{array}{l}\text { Positive GD }\left(^{*}\right) \\
\text { at D18 }(\%)\end{array}$ & $\begin{array}{l}\text { Pregnant } \\
\text { ewes (\%) }\end{array}$ & $\begin{array}{c}\text { No lambs } \\
\text { No blastocystes }\end{array}$ & & $\%$ \\
\hline $\begin{array}{l}\mathrm{B} 2-37^{\circ} \mathrm{C}-1 \mathrm{~h} \\
\mathrm{~B} 2-37^{\circ} \mathrm{C}-5 \mathrm{~h}\end{array}$ & $\begin{array}{l}41.7(5 / 12) \\
41.7(5 / 12)\end{array}$ & $\begin{array}{l}25(3 / 12) \\
17(2 / 12)\end{array}$ & $\begin{array}{l}3 / 17 \\
2 / 19\end{array}$ & $\left.\begin{array}{l}17.6 \\
10.5\end{array}\right\}$ & $\bar{M}=14 \%$ \\
\hline $\begin{array}{l}199-37^{\circ} \mathrm{C}-1 \mathrm{~h} \\
199-37^{\circ} \mathrm{C}-5 \mathrm{~h}\end{array}$ & $\begin{array}{l}90.0(9 / 10) \\
25.0(1 / 4)\end{array}$ & $\begin{array}{l}60(6 / 10) \\
25(1 / 4)\end{array}$ & $\begin{array}{l}7 / 15 \\
1 / 6\end{array}$ & $\begin{array}{l}47 \\
17\end{array}$ & \\
\hline $\begin{array}{l}\mathrm{B} 2-20^{\circ} \mathrm{C}-1 \mathrm{~h} \\
\mathrm{~B} 2-20^{\circ} \mathrm{C}-5 \mathrm{~h}\end{array}$ & $\begin{array}{l}89.0(8 / 9) \\
89.0(8 / 9)\end{array}$ & $\begin{array}{l}66(6 / 9) \\
66(6 / 9)\end{array}$ & $\begin{array}{l}8 / 16 \\
10 / 22\end{array}$ & $\left.\begin{array}{l}50 \\
45\end{array}\right\}$ & $\bar{M}=47.5 \%$ \\
\hline
\end{tabular}

(*) Gestation diagnosis.

The numbers in parenthesis in the first column are the numbers of ewes used.

\section{Discussion.}

The use of porcine pituitary extract (pFSH) to superovulate ewes showed the following results.

The ovarian response and the interval between sponge withdrawal and oestrus onset varied according to the origin of the pituitary extract; it seems important in the future to be able to use hormones with precise and nearly constant FSH/LH activity (Combarnous, personal communication). Responses varied widely between animals, whatever the composition or mode of injection (constant or decreasing doses) of the pituitary extract used. The higher ovulation rate obtained with the injection of constant pFSH doses (lot B) must be confirmed in ewes under other conditions. Monniaux et al. (1983) have shown that, compared to constant doses, decreasing doses of pFSH in cows elevate the ovulation rate and the number of good embryos recovered. Mutiga and Baker (1982) recorded the same individual variability in stimulations induced with $1000 \mathrm{IU}$ of PMSG, but for a mean $\mathbf{5 . 7}$ eggs recovered (from 7.5 corpora lutea), 3.4 were transferable and the number of non-ovulatory follicles reached $3.4 \pm 0.72$. With the pFSH treatment, the number of follicles decreased (lot $B$ and $\mathrm{C}$ ) and the proportion of good embryos was clearly better.

As the experiment lasted 3 months, the different lots of pFSH were used successively. It was therefore impossible to compare survival after the transfer of embryos which were obtained by the three methods of superovulation and which received the same storage treatment. 
The follicular luteinization that we observed previously during the first week following the end of the treatment (Torrès et al., 1983) could cause error in calculating the percentages of embryos recovered. Monniaux et al. (1983) have made the same observation in cows. These cystic non-ovulatory follicles could be confused with corpora lutea at D6, resulting in an underestimate of the yields.

A comparison of two treatments (PMS and FSH) by Armstrong and Evans (1983) led to the same conclusions. The number of non-ovulatory follicles was higher with PMSG and the proportion of transferable embryos higher with FSH (5.3 vs 3.5).

Contrary to the results of Armstrong and Evans, we did not note a decrease in the number of good-quality embryos when superovulation was higher than 8 corpora lutea (see regression lines on fig. 1).

The presence of unfertilized eggs cannot be attributed to either sperm failure or excessive superovulation since these eggs were found more frequently in ewes with few corpora lutea. When the eggs were examined under a microscope, we found no spermatozoa in the zona pellucida; this could be a result of delayed ovulation.

Surgical recovery permits recipient ewes to be used as donor ewes after two cycles without treatment. Lesions due to surgery could make the fertility of these ewes questionable ; surgically placing one embryo per uterine horn gives a good chance of success.

Embryo storage at $37^{\circ} \mathrm{C}$ was very limited; the small number of transfers carried out in two media and after two storage times did not permit us to draw valid conclusions. However, lowering storage temperature to $20^{\circ} \mathrm{C}$ clearly improved embryonic survival. It is probable that maintaining the metabolism at $37^{\circ} \mathrm{C}$ and draining the embryonic stores caused the high rate of embryonic loss after transfer.

This experimentation, which has to be adapted before it is practical, permitted us to develop a superovulation treatment yielding a proportion of good embryos which has not been obtained previously.

Reçu en mars 1984. Accepté en juin 1984.

Acknowledgements. - We wish to thank Mrs. Claude Sevellec, Mr Bernard Dare, and Miss Aline Solari for their efficient assistance.

Résumé. Transfert des oeufs superovulés chez la Brebis.

45 Brebis Préalpes sont superovulées par un traitement comprenant la pose d'éponges intravaginales imprégnées de $40 \mathrm{mg}$ de FGA et l'injection au retrait de l'éponge, de $12 \mathrm{mg}$ d'extrait hypophysaire porcin (pFSH). Les 57 Brebis receveuses sont traitées avec $500 \mathrm{UI}$ de PMSG en injection i.m.

Deux lots de pFSH sont utilisés (lot pFSH 1 pour l'expérience $A$; lot pFSH2 pour les expériences $B$ et $C$ ). Les $12 \mathrm{mg}$ de pFSH sont administrés soit en 4 injections de $3 \mathrm{mg}$ (expérience $A$ et $B$ ) soit en injections dégressives de 5, 4, 2 et $1 \mathrm{mg}$ (expérience $C$ ). La variabilité des réponses individuelles des Brebis aux traitements de superovulation est importante quel que soit le lot de FSH injecté. Dans les extraits hypophysaires, le rapport 
FSH/LH paraît plus important que la répartition des $12 \mathrm{mg}$ injectés. Les embryons sont récupérés chirurgicalement à $\mathrm{J} 6$.

La proportion d'embryons viables par rapport au nombre de corps jaunes est de 33 sur $56(59 \%)$ pour le lot A, 46 sur $67(69 \%)$ pour le lot B et $62 / 78(79 \%)$ pour le lot C.

Les morula/blastocystes sont mis en place chirurgicalement après conservation dans le milieu 199 ou le milieu B2 (Ménézo, 1976) $+10 \%$ de SVF soit à $37^{\circ}$ soit à $20^{\circ} \mathrm{C}$.

La conservation des embryons $1 \mathrm{~h}$ ou $5 \mathrm{~h}$ à $37^{\circ} \mathrm{C}$ dans le milieu $\mathrm{B} 2$ ne donne que $14 \%$ (nombre d'agneaux nés/nbre morula ou blastocystes) de mise-bas. Dans le milieu 199 à $37^{\circ} \mathrm{C}$ après $1 \mathrm{~h}$ de conservation on obtient $47 \%$ de mise bas et après $5 \mathrm{~h}: 17 \%$. L'abaissement de la température de conservation à $20^{\circ} \mathrm{C}$ permet d'obtenir 50 et $45 \%$ de mise bas respectivement après $1 \mathrm{~h}$ et $5 \mathrm{~h}$ de conservation.

\section{Références}

ARMSTRONG D. T., EVANS G., 1983. Factors influencing success of embryo transfer in sheeps and goats. Theriogenology, 19, 31-42.

COGNIÉ Y., MARIANA, THIMONNIER J., 1970. Étude du moment d'ovulation chez la brebis normale ou traitée par un progestagène associé ou non à une injection de PMSG. Ann. Biol. anim. Biochim. Biophys., 10, 15-24.

HUNTER G. L., ADAMS C. E., ROWSON L. E. A., 1955. Interbreed ovum transfer in sheep. J. agric. Sci., 46, 143-149.

MÉNÉZO Y., 1976. Milieu synthétique pour la survie et la maturation des gamètes et pour la culture de I'œuf fécondé. C.R. Acad. Sci. Paris, sér. D., 282, 1967-1970.

MOORE N. W., SHELTON J. M., 1964. Effect of degree of synchronization between donor and recipient, age of egg, and site of transfer on the survival of transferred eggs. J. Reprod. Fertil., 7, 145-152.

MONNIAUX D., CHUPIN D., SAUMANDE J., 1983. Superovulatory responses of cattle. Theriogenology, 19, 55-81.

MUTIGA E. R., BAKER A. A., 1982. Superovulatory response in merino ewes to three PMSG dose levels. Theriogenology, 17, 100.

ROBINSON T. J., 1965 . Use of progestagen impregnated sponges inserted intravaginally or subcutaneously for the control of the oestrous cycle in the sheep. Nature, 206, 39-41.

ROWSON L. E. A., MOOR R. M., 1966. Embryo transfer in the sheep; the significance of synchronizing oestrus in the donor and recipient animal. J. Reprod. Fert., 11, 207-212.

SHELTON J. M., MOORE N. W., 1967. The response of the ewe to pregnant mare serum and to horse anterior pituitary extract. $J$. Reprod. Fert., 14, 175-177.

TORRĖS S., REBOURS C., ROMBAUTS P., ANDRÉ D., BERTIN J., TERQUI M., 1983. Conditions of embryonic development in the ewe after modification of the hormone balance of the dam. Anim. Reprod. Sci., 6, 25-33.

WITENBERGER-TORRĖS S., 1967. Etude expérimentale de la migration tubaire des oufs et de leur segmentation chez la Brebis. Thèse CNRS A.0.1493. 